\title{
HOSTING MEGA SPORT EVENTS IN A SMALL COUNTRY: THE (REAL) IMPACT ON THE DEVELOPMENT - CASES OF CROATIA AND SERBIA ${ }^{* * *}$
}

Majority of studies on the impact of the sports events on country's development are produced before the events take place and as such are in favour of the bidding process. When comparing these ex ante analyses to the ex post evidence, it has been in most cases obvious that they have been overly optimistic. This paper analyses the ex ante analysis provided by the Croatian bidding committee for the European Football Championship 2012. In addition to that, the ex ante study for the World Handball Championship 2009 in Croatia and (insufficient) data for the handball championships that took place in Serbia were analysed as well. This paper contributes both to the debate on the realistic approach of several failed and won bids, and the debate on the future bids for the other sport events.

Key words: economics of sports, management and organisation, sport events, championships

* PhD, Assistant Professor, Department of Economics, Faculty of Law, University of Zagreb, e-mail:ruzica.simic@pravo.hr

** PhD, Assistant Professor, Faculty of Geoeconomics, John Naisbitt University, Belgrade, e-mail: ajurcic@naisbitt.edu.rs

*** PhD, Assistant Professor, Faculty of Sport and Physical Education, University of Belgrade, e-mail: milan.petronijevic@fsfv.bg.ac.rs

**** This paper is a part of the project within Ministry of Education, Science and Technological Development of the Republic of Serbia. (ID number 47004) - The enchantment of public policies in Serbia in the function of improving social security of citizens and sustainable economic growth. 


\section{Introduction}

Major sports events have become an increasingly analysed issue. In the recent decades they have been catching big attention of the policy makers, academics, spectators, media and business people. When analysing the impact of the major sport events on the development of the city the distinction should be made between North America and the rest of the world. During last decades the cities in the USA have been trying to attract professional sport teams from their existing host cities by building better infrastructure for their sports, while in Europe the strategy is based on hosting the major sports events. ${ }^{1}$ Another parallel distinction is that city marketing is the issue that has been much longer researched in the US than in Europe. ${ }^{2}$ Following these statements, besides the theoretical background, European case studies were used in this paper, predominantly the ones from Germany and the UK. In some cases, the summarized findings from the analyses of the impacts of the Olympics, European and World Championships were used as well. Moreover, one of the authors of this article was a member of the organising committees of the handball championships in Serbia, so we use the position of the researcher - insider ${ }^{3}$ in order to compensate for the lack of relevant data and validate the official data obtained from the Serbian Handball Federation.

Sport plays a very important role at various levels in the Croatian society. In the Croatian Strategic Development Framework ${ }^{4}$ the sport spirit is pointed out as one of the main national values and a social cohesion driver. The same document emphasises that "out of all winter and summer Olympic sports, Croatia - a country constituting about $0.0007 \%$ of the world population - has champions or the best individuals in as many as 3 sports out of 35, or in $9 \%$ of the total number

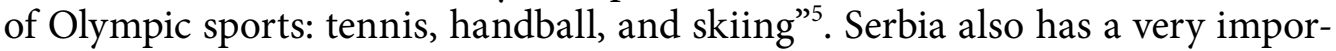
tant role and a good tradition in several sport disciplines. Team sports are a part of Serbian legacy but on last Olympic Games in Rio 2016, there was an equal share of medals between sport games and individual sports (athletics, wrestling, taekwondo and canoeing).

1 Gratton, C., Shibli, S., Coleman, R. (2006): “The economic impact of major sports events: a review of ten events in the UK", The Sociological Review, Vol 54, No. 2, 41-42.

2 Paddison, R.(1993): "City Marketing, Image Reconstruction and Urban Regeneration", Urban Studies, Vol. 30, No. 2, 340.

$3 \quad$ Banks, J. A. (1998): “The Lives and Values of Researchers: Implications for Educating Citizens in a Multicultural Society“, Educational Researcher, 27(7), 4-17.Chavez, C. (2008): "Conceptualizing from the inside: Advantages, complications, and demands on insider positionality“, The Qualitative Report, 13(3), 474-494.

4 Government of the Republic of Croatia: Strategic Development Framework for 2006-2013. Central Office for Development Strategy and Coordination of EU Funds. Zagreb, August 2006, http://www.strategija.hr/datastore/filestore/16/Strateski_okvir_za_razvoj_2006_ 2013.pdf . (10. September 2014)

5 Ibid, 33. 
Going back to the beginning of one of the researched initiatives, in December 2004 Croatian and Hungarian Football Associations supported by the Croatian and Hungarian Governments signed the agreement on joined bidding for the European Football Championship in 2012. The mayors of the candidate host cities signed the assurances on behalf of the cities of Zagreb, Osijek, Rijeka and Split. And the intense bidding process began. Great expectations, lots of enthusiasm, many people and lots of financial resources were involved.

The opportunity for Croatia, that was bidding together with Hungary, to host the European Football Championship in 2012 was one of the most discussed topics among politicians, businessmen, representatives of the sport associations, and above all among the sport fans, not to mention general public. Almost all the stakeholders, especially the bidding team members, were extremely enthusiastic, had great expectations and offered endless promises. It was announced as an event that would trigger a huge spectrum of positive impacts on Croatian economy and society. The mayors of the prospective host cities Zagreb, Rijeka, Split and Osijek were strongly involved emphasising it as an urban regeneration opportunity. In April 2007 UEFA reached the decision; Croatia did not get the opportunity to host EURO 2012. The national disappointment was immense. The aim of this paper is to analyse if this mega sport event could really have produced a net positive long term impact as announced, or it would be bottom line 'bread and circuses' only. Should the national disappointment about not hosting the event actually be a national relief?

Zagreb as the capital is usually 'accused' of being the main magnet for public investments. It is the most developed city in the country with the highest GDP per capita, public administration and most of the companies are based in Zagreb. Rijeka and Split are situated on the Adriatic coast, and significant share of revenues in these cities comes from tourism. Osijek, a city in Eastern Croatia that suffered heavily during the war, is still doing some basic infrastructure renewal in the surrounding region and trying to resolve the unemployment problems.

In theory and in practice the most common holy trinity of mega events' benefits stated by the supporters is the economic growth, infrastructures legacy and image promotion. ${ }^{6}$ However, causality should be the determining factor that means only impacts that will happen because of the event taking place there. Most analysts disagree regarding the magnitude of the impacts, but they mostly agree on their nature. ${ }^{7}$ This analysis includes the economic impact, infrastructure, image promotion as well as the country and time specific impacts: social, political and tourism; all of those in order to assess the realistic effects that analysed events might trigger.

$6 \quad$ Matos, P.(2006): (According to Preuss, 2001):: "Hosting mega sports events: A brief assessment of their multidimensional impacts", Paper presented at The Copenhagen Conference on the Economic and Social Impact of Hosting Mega Sports Events, Copenhagen, September 2006, 2.

Ibid. 


\section{Economic impact and infrastructure legacy}

Economics of sports evaluates social and economic impacts of sports; yet, the emphasis is on economic impacts that can be precisely measured. ${ }^{8}$ Economic benefits are the prime motive for hosting the mega sports events, that means increased employment, spending of spectators, 'showcase effect' etc. ${ }^{9}$ It is also claimed that 'in the UK and Australia the main stimulus for using sport for economic regeneration has been the hosting of international sporting events. ${ }^{10}$ In terms of economic importance EURO is considered a Type A in the typology for major sports events, which is 'irregular, one-off, major international spectator events generating significant economic activity and media interest.'. ${ }^{11}$ Many authors have already recognized that 'given the complex nature of the economic structure of regions and countries, estimating the total economic impact is fraught with difficulties', but still officials use this fact as a major argument of hosting the events. ${ }^{12}$ In case of Croatia, this gives the argument to observe these cities as one unit in terms of overall economic impact. In general, it has become quite clear that despite headlinesdriven expectations, Olympics for instance are "a money-losing proposition for host cities; they result in positive net benefits only under very specific and unusual circumstances" and if money-winning, then it is the case in developed countries and not in developing countries. ${ }^{13}$ That is why the economic gains from hosting the mega sporting events are increasingly considered to be illusory. ${ }^{14}$ Despite the fact that Serbian Handball Federation in just 23 months (January 2012- December 2013) hosted three major sport events (2 EUROs and one World Cup), with officially positive net benefits, reality shows more of a "money losing" proposition. However, it is important to note that the only document ${ }^{15}$ provided by the Serbian Handball Federation does not supply enough evidence for (deeper) analysis of any of the aspects presented in this paper.

The interest in the economic impact when organising the major sports events has increased and that is why the bidding cities want to present a realistic cost8 Bartoluci, M.(2003): Ekonomika i menedžment sporta, Informator Zagreb i Kineziološki fakultet Sveučilišta u Zagrebu, Zagreb, 75-83.

9 Horne, J. (2007): “The Four 'Knowns' of Sports Mega-Events", Leisure Studies, Vol 26, No. 1,85 .

$10 \quad$ Ibid, 87.

11 Gratton, C., Dobson, N., Shibli, S. (2000): "The economic importance of major sports events: a case study of six events", Managing Leisure, Vol 5, 25-26.

12 Matos, P., 5.

13 Baade, Robert A., Matheson, Victor A. (2016): The Journal of Economic Perspectives, Volume 30, Number 2, April 2016, 201-218(18).

14 Zimbalist, A. (2015): "The Illusory Economic Gains from Hosting the Olympics\& World Cup“, World Economics, vol. 16, issue 1, 35-42.

15 RukometnisavezSrbije: IzveštajsaEvropskogprvenstvaSrbija 2012., http://rss.org.rs/files/ Izvestaj_sa_Evropskog_prvenstva_Srbija_2012.pdf (22.December 2016) 
benefit analysis. ${ }^{16}$ But predicting the impact by using the ex ante analysis can produce errors like model uncertainty, model parameters might also be subject to uncertainty, and there is variable uncertainty as well. ${ }^{17}$ These events could be argued as paradoxical when bearing in mind that they are temporary on the one hand, but on the other their costs are substantial. Another 'red flag' when trying to get the objective picture is that policy makers will usually be in favour of the studies that present positive net economic outcomes. ${ }^{18}$

Financial impact will be analysed within the economic impact. The unequivocal fact about the bidding cost is that they also extend to those who lose. ${ }^{19} \mathrm{Croatia}$ ended up this bidding process with the minus of $2000000 €$. Had Croatia won the Championship, it would have been only a small part of the overall costs that were estimated on approximately $750000000 € .^{20}$ Although Croatian Football Federation Officials were very proud of the bidding proposal that with full documentation contained 13.500 pages, it was not publicly available. In the media and on the official web site there were only the highlights containing main data and promoting the benefits. It could be argued that this necessarily raises the issue of the transparency, and the overall accountability of the organising committee. Giving only the information in the form of short press releases for an event that would bring enormous costs to the tax payers does not seem to be sufficient enough.

As questioned when Greece, the poorest 'old' EU member state, organised the Olympics, the same could be questioned for Croatia, the EU candidate country forced to implement many reform processes; is it really necessary that a huge amount of public money is spent for a sports event if at the same time basic infrastructure, health and education system need to be improved. ${ }^{21}$ The Croatian officials argued that a share of estimated expenditure would be spent not only for the sports facilities, but also for the roads and buildings, and by doing so the whole project would certainly contribute to urban renewal. ${ }^{22}$ Another argument that officials raised was that the stadium costs would be $367000000 €$, and that is almost the half of the overall costs, but they would be refurbished and/or built through public-private partnership, and in that way only a part of the stated amount would be a burden for the state budget. ${ }^{23}$

16 Sterken, E. (2006): "Growth Impact of Major Sporting Events", European Sports Management Quarterly, Vol. 6, No. 4, 375.

$17 \quad$ Ibid, 377.

18 Matos, P., 5.

19 Ibid, 4.

20 Jutarnji list (2007a): "Hrvatskoj u mjesec dana Eura milijarda kuna samo od PDVa”, 01. April 2007. http://www.jutarnji.hr/clanak/art-2007,4,1,,68703.jl (05. September 2015)

${ }^{21}$ The Economist (2004): A matter of priorities; those Olympic Games. Greece's costly Olympic Games, Sept 4, v372, i8391, 13 US

22 Jutarnji list (2007a)

23 Jutarnji list (2007b): “Euro 2012. stajat će nas 5,5 milijardi kuna”, 25. February 2007.http:// www.jutarnji.hr/clanak/art-2007,2,25,markovic_hns,64104.jl(12. September 2015) 
There is a known optimism bias in planning; almost all the mega projects are not delivered anywhere on time or within the budget. ${ }^{24}$ Delays create additional costs that were not included in the Croatian bid. The maintenance costs were not taken into account in the Croatian bid as well. It has been well known that the maintenance costs for the flagship buildings are immense, and if they are underused, they create significant minuses. And that would be the case in Croatia because none of these cities is capable of organising events and regular activities to pay off the bills, even that publicly funded share. There were supposed to be 1,300.000 tickets on sale for EURO 2012, and that is impressive considering the number of people attending the events, but in terms of direct financial impact for Croatia the net sum is significantly smaller because of the UEFA rights.

The forecast was that EURO 2012 would create 50000 new work places in Croatia and Hungary, and that investments in stadiums would indirectly increase economic growth. ${ }^{25}$ The key questions when assessing the employment opportunities are: 'what kind of jobs are to be created - part-time or full-time, temporary or permanent, and for whom? ${ }^{26}$ At the same time it remains unclear how many jobs would be created in Croatia. Furthermore, it was not stated how many of these jobs were only temporary for the purposes of the event. Although even temporary jobs are not to be underestimated, it is the fact that during summer season in Croatia there are seasonal jobs in the tourism and construction anyway, so the net creation of new jobs would not be significant as announced.

Another example of the analysis of hallmark event that took place in 2009 shows similar lacking aspects of economic impact and infrastructure legacy assessment. Even though the problems with the economic impact estimates are clearly listed in the ex ante study prepared for the Croatian Handball Federa$\operatorname{tion}^{27}$ and the reasons for overestimation of the benefits are explained ${ }^{28}$, there are still plenty of facts in the ex post analysis that most probably should be revised. One of the questionable facts is the estimate of 4000 visitors per day spending EUR 150 that would in total make EUR $12 \mathrm{mln}$ of net revenues for Croatia. ${ }^{29}$ Furthermore, the final costs of staging the World Handball Championship were still not known a week before the event took place. ${ }^{30}$ Another questionable issue is the

\footnotetext{
24 Horne, J., 91.

25 CFF - Croatian Football Federation Official Website http://www.hns-cff.hr/?ln=en(10. April 2012)

26 Horne, J., 89.

27 Hrvatski rukometni savez (2006): “Utjecaj ekonomike sporta na gospodarstvo i razvoj Hrvatske - Hrvatska domaćin Svjetskog prvenstva u rukometu za muške“, Zagreb, listopad 2006.

28 Ibid, 17-18.

29 Ibid, 23-34.

30 Raguž, K. (2009): Zlatko Mateša: Još ne znamo kolika će biti konačna cijena održavanja Svjetskoga rukometnog prvenstva. Intervju. 08. January 2009., http://www.liderpress.hr/
} 
maintenance costs and management of the Arena Zagreb and other major newly built sport arenas that despite many tangible and intangible benefits became the source of confusion and misunderstandings among city officials and managers and companies in charge of them in various stages. ${ }^{31}$ For instance, it has been calculated that to reach the break-even point of buildings similar to Arena Zagreb, the building needs to host the events at least 200 days a year with the minimum ticket price of EUR $20 .{ }^{32}$ It was highly unlikely that this would happen, especially when bearing in mind that there are already existing buildings in Croatian capital that are causing great expenses. ${ }^{33}$ In retrospect, it is evident that afore mentioned 200 days were not reached in any of the years following the Handball championship. Moreover, even the legacy of sports facilities on host communities in developed countries hosting the Olympics is questionable as the studies find little or no economic benefits since they are mostly left unused after the Games and produce high and long-term maintenance costs. ${ }^{34}$

Despite many similar negative economic impacts that have already been mentioned, Serbian Handball Federation in its bidding documentation for EURO 2012 announced to build a new multifunctional sports hall in the city of Niš with estimated costs of 14 million $€$. Due to the careful auditing and awareness that this project may cause severe economic consequences, in the last bidding phase it was decided to abandon the initial plan and to make full reconstruction of already existing sport hall "Čair" for significantly smaller budget of 6 million $€$.

\section{Tourism and image promotion}

In case of major sport events the concept of sport marketing is applied on sport as a product whereby the audience and the direct actors are treated as a market. ${ }^{35}$ It is recognised that two main features of contemporary mega events are significant consequences for the host cities, and great media coverage that they will attract. ${ }^{36}$ They are also seen as an important part of the tourism strategy

Default.aspx?sid=64099 (15. July 2015)

$31 \quad$ Žabec, K. (2008): “Dvorane su gotove, tko će ih puniti”, 14. December 2008., http://www. jutarnji.hr/nedjeljni_jutarnji/clanak/art-2008,12,14,,144937.jl (20. December 2015).

32 Nekić, M., Kulenović, A. (2008): “Upravljanje sportskim dvoranama“,26. October 2008. http://www.liderpress.hr/Default.aspx?sid=57956(15. July 2015)

33 Jutarnji list (2010): “Financijskecrnerupe: SamoobavezniWC-iuMaksimirustoje 100.000 knpoutakmici!“, 05. September 2010.

34 Baade, Robert A., Matheson, Victor A., 201-218(18)

35 Bartoluci, M., 259-261.

36 Horne, J., 81-82.

Vol. 14, № 2, 2017: 273-290 
that is linked to urban renewal processes. ${ }^{37}$ The raising attractiveness of mega sport events is due to three key reasons: advancements in mass communication, especially the satellite television creating global audiences; increased corporate sponsorships since 1984 Olympics; and finally, highly influenced by the previous two factors, promotional opportunities for cities and regions, as well as the opportunity to sell event-related products. ${ }^{38}$ One of the most recent examples is 2014 Winter Olympics in Sochi that is considered to be the most expensive Olympic Games and hand the highest share of public funding; total costs were $\$ 55$ billion that was 4.5 times more that stated in the initial bid. Yet, the image of Russia in the world wasn't improved and the domestic population had continuously decreased its support for the event. ${ }^{39}$

As already stated, EURO is a Type A event that means 'spectator driven' and spectators are generating the vast majority of additional revenues. It was estimated that in average 150000 people per day will be in Croatia during 30 days, and that would be a total of 4500000 overnight stays, and if that is multiplied by average accommodation price and daily spending of 100 to $170 €$, the total amount was supposed to be between 450 to $750 \mathrm{mln} €{ }^{40}$ These analyses do not take into account the tourists that would postpone their trip to Croatia because of the event. This phenomenon (might be called 'net arrival of tourists') occurs during all major sports events. It has to be taken into account as well that many tourists would come from neighbouring countries and would not stay overnight in the hotels, but rather drive back home. Regarding the average daily consumption of the tourist, if comparing with the usual statistical data, it can be claimed that it is too optimistic especially when having in mind that the organising committees were targeting mostly younger population including the backpackers.

It is questionable if an opportunity for Croatia as a tourist destination could be so called 'nostalgia sport tourism" ${ }^{41}$ because the events that took place before in Croatia were not of Type A and there are only few small halls of fame. The obvious opportunity for Croatia is to promote the extended stay of tourists in Croatia after the EURO by proposing different destinations at the seaside, in the mountains, and in the continental part. This could contribute not only to the host cities, but also to the places that are not hosting the Championship, hence creating a sort of synergy effect in regional tourism development. However, Rijeka and Split and their surroundings would probably have the biggest

\footnotetext{
37 Gratton, C., Shibli, S., Coleman, R. (2005): "Sport and Economic Regeneration in Cities“, Urban Studies, Vol 42, No. 5/6, 985-999.

38 Horne, J., 83-84.

39 Mueller, M. (2014): “After Sochi 2014: costs and impacts of Russia's Olympic Games“, Eurasian Geography and Economics, Vol. 55, No. 6, 628-655.

40 CFF - Croatian Football Federation Official Website

$41 \quad$ McCartney, GJ. (2005): “Hosting a recurring mega-event: Visitor raison d'etre“, Journal of Sport and Tourism, Vol. 10, No. 2, 116.
} 
benefits from the extended stay of tourists because of the summer season and tourists' preferences at that time. As handball events are not considered as Type A, major impacts on tourism during EURO and World Cup in Serbia were not reported. As those events were played during low touristic season (December and January), larger use of hotel capacities in hosting cities were notified.

It is argued by the organising committee officials that the promotion that Croatia would get as tourist country through EURO is invaluable. For instance, for the EURO in Portugal there were 22.500 hours of TV coverage, and UEFA internet site Portugal 2004 was visited more than 700000000 times. ${ }^{42}$ In addition to that, as already stated, selling event-related souvenirs is a common source of income for the local businesses and licence-owners and should have a lasting effect through 'nostalgia tourism'. Yet, the anecdotal evidence shows that despite high investments in their design and production most of the mascots from the events in Croatia and region were not really successful - both according to the experts' opinion and measured by the time they were recognized in the medium and long run. ${ }^{43}$

\section{Social impact}

City marketing is often closed in economic terms and hence does not include wider important societal implications. ${ }^{44}$ Many case studies of the major sports events show significant increase in national pride and confidence that cannot be easily measured, but is obviously present everywhere. This cannot be taken as an overall straightforward signal. For instance, in case of 2006 Football Cup in Germany, the perception of residents in Munich about the impacts was largely positive, but the organized crime for example was much greater issue than the residents perceived. ${ }^{45}$

It was argued that in case of staging EURO in Croatia, new generations would get new 'sport heroes' like they had in the famous Croatian national team during 1990s. Reportedly, sport facilities investments would improve the quality and standards of watching football games in four biggest cities in Croatia, and professional football would attract new capital in the football schools and enable the physical and social infrastructure for the future medal winners. ${ }^{46}$ It could be

42 CFF - Croatian Football Federation Official Website

43 Jutarnji list (c). "Dobili smo još jednu maskotu koju ćemo vrlo brzo zaboraviti“ 23. August 2010., http://www.jutarnji.hr/dobili-smo-jos-jednu-maskotu-koju-cemo-vrlo-brzo-zaboraviti/879987 (05. September 2015)

$44 \quad$ Paddison, R., 340.

45 Ohmann, S., Jones, I., Wilkes, K.(2006): “The Perceived Social Impacts of the 2006 Football World Cup on Munich Residents“, Journal of Sport and Tourism, Vol 11, No. 2, 129-152.

46 CFF - Croatian Football Federation Official Website 
suggested that on one hand all these stadiums could be used not only for football, but also for some other sport like athletics. But on the other hand the question on the selection of the investment targets remains open, i. e. why investing that much in the sport facilities that could be used only for some selected sports when there are other sports in Croatia that are either achieving better results, or would be able to attract capital and even improve their results if they had better infrastructure conditions. In the meantime, since the bid for EURO 2012, World's Men Handball Championship in 2009 and European Water Polo Championship in 2010 were organized in Croatia.

The latest survey found that $87 \%$ of the Croatian population supported the idea of hosting the EURO 2012. ${ }^{47}$ This could be a good argument since most of them are tax payers. Still that does not mean that they are well informed tax payers. Croatian people with their Mediterranean character are mostly driven by passion and hence represent a good ground for 'bread and circuses' effects. The usual comment in the streets was: 'We will pay taxes anyway, so let us at least pay it for the fun purposes!' With regard to the current crisis and announced lack of funding for basic needs of the citizens and problems with paying off the debts, it is very likely that the common answer would change. However, there is still widespread lack of understanding of causal effects of government spending and dangers of overindebtness, and at the same time common practice of headlines-driven political and economic decisions. It is the fact all over the world that 'during the mega events the identities of local people are meant to conform to the (generally) positive stereotypes contained in the pre-event publicity and the opening ceremonies' ${ }^{48}$ Yet, mega events could be very seductive, and they cannot be seen as a panacea for economic and social problems. ${ }^{49}$

\section{Political impact}

Croatian and Hungarian Prime Minister, as well as other ministers were very engaged in the bidding process. They were emphasising it as a cooperation of a new EU member country and (at that time) future EU member country. The decision about bidding in cooperation with Hungary was above all practical reasons a political decision as well. It was claimed that the staging of this event would encourage political and economic ties of these two countries and of the other neighbouring countries as well. In addition, it was supposed to attract many influential business and political people to Croatia, as well as accelerate improvements in the infrastructure and encourage some reform processes in the society. Bottom line it was supposed to have positive political impact. From the

\footnotetext{
$47 \quad$ Ibid.

48 Horne, J., 90.

49 Ibid,91-92.
} 
more cautious point of view, bearing in mind effects like redistribution, crowding out and higher Croatian public and foreign debt (most of the indicators were already at that time too close to Maastricht criteria limits), than rise of corruption and crime, it would not be politically well accepted on the Croatian way towards EU. From the other point of view, 2007 was an electoral year in Croatia, in light of that fact, any gains, even the ones of hosting mega events, would probably ensure some voters for the party in power.

\section{Overall development effects}

There is a wide spread opinion that 'sport events can act as a catalyst for economic development and urban regeneration. ${ }^{50}$ On the other hand, after analysing the attempts of using sport events for the urban regeneration in UK, Europe and Australia, Gratton and Henry claimed that 'potential benefits have not yet been clearly demonstrated, and actually rare places are known for their success in social and urban regeneration. ${ }^{51}$ Barcelona Olympic Games was one of the rare examples that is considered as successful both as event and in terms of overall urban changes connected with the economic development ${ }^{52}$, 'Barcelona paradigm' is discussed as the best model to assess design-led urban regeneration strategies. ${ }^{53}$ Most recently, the environmental issues have been increasingly emphasised; academics showed great interest for that when researching Olympic Games in China. ${ }^{54}$

A significant share of funding for EURO 2012 was supposed to be received from central government that means all the Croatian tax payers, and altogether less than the a third of Croatian population lives in these cities. It may be argued that this is not fair and that it would even widen the development gap between these four cities and other urban and rural areas. Even if this fact is disregarded or supported by some contra arguments with the knock-on effects and infrastructure improvements for Croatia as a whole, there is also a rising concern about which social group is a winner in these cities. It can be argued that, very similar to the findings in other relevant case studies, the biggest part of the benefits will go to the businesses that would not necessarily create a significant num-

$50 \quad$ Wilson, R. (2006): “The economic impact of local sport events: significant, limited or otherwise? A case study of four swimming events", Managing Leisure, Vol. 11, No. 1, 57.

51 Horne, J., 87-88.

$52 \quad$ Monclus, F-J. (2003): “The Barcelona model: and an original formula? From 'reconstruction' to strategic urban projects (1979-2004)“, Planning Perspectives, Vol 18, No. 4, 399-421.

53 Bell, D., Jayne, M. (2003): “ 'Design-led’ Urban Regeneration: a Critical Perspective“, Local Economy, Vol. 18, No. 2, 121-134.

54 Chanaron, J.J. (2014): “Technology and Economic Impacts of Mega-Sports Events: A Key Issue? Exploratory Insights from Literature“, Megatrend revija, Vol. 11, No. 4, 9-30. 
ber of temporary jobs or some other sustainable legacy for the most endangered social groups, as it is claimed by the public officials. Most of the investments would be 'brown field' usually providing only temporary employment like the refurbishment of buildings. In case of land needed for the green field investment for some major event, a regulation similar to Compulsory Purchase Order in UK is applied in Croatia. Because of that up to now many cases of direct corruption or clientelistic decisions have been registered or speculated. Even when the big infrastructure investment like building the stadium is finished, another almostPandora-box opens, and it is named maintenance costs. This is only about one infrastructural project, having this situation multiplied several times would in current conditions bring even more concerns about overall accountability, and adding the already stated optimism bias in planning, the urban development mess is highly probable.

\section{Conclusion}

The assessments in this paper are based on publicly available official data that are related to and relevant for the researched events. These data were then analysed based on the theories and empirical evidence of the mega sport events impacts on the cities, in particular urban and economic development processes, but above all findings of the case studies of relevant sports events and their influence on overall urban and economic development. The impact possibilities of major sport events were assessed through many aspects and were approached holistically in order to get the most objective 'big picture' answer on the research question.

In short, if the balance sheet consisting of emotions of the population was made, the result would be in favour of 'bread and circuses' option. Based on the arguments on economic, social, political, infrastructure, image and tourism impacts which were presented in the paper, overall net positive impacts based on ex ante study seem to be too optimistic, the same as in the majority of cases that were comparatively explored. It is certain that some developmental projects would be initiated by those mega events, yet their cost-benefit impact and long term result would most probably be negative. The cost-benefit analyses of the researched cases seemed to be ambiguous at best. It seemed that UEFA helped Croatia by letting it find other, hopefully more efficient ways of urban and economic development push for its major cities, and at the same time probably saved some money of the insufficiently informed taxpayers. On the other hand, despite some positive effects for the parties included, the handball championships in Serbia and Croatia produced numerous long-term maintenance costs and questionable long-term social and tourism effects. The findings of this paper are deemed to be in line with one of the most recent studies on hosting the Olympics: 
"The goal should be that the costs of hosting are matched by benefits that are shared in a way to include ordinary citizens who fund the event through their tax dollars. In the current arrangement, it is often far easier for the athletes to achieve gold than it is for the hosts." 55

The purpose of this paper was not to give a straightforward advice on whether it is worth organizing a major sport event in a small transition country like Croatia or Serbia. The purpose was rather to highlight the major aspects that need to be thoroughly analysed when some event is taken into consideration and eventually planned by major sport authorities in the country. However, the majority of cases showed many deficits in the presentation of the benefits of selected events in Croatia in Serbia; the same as missing indicators, expertise and clarity in ex ante studies.

$55 \quad$ Baade, Robert A., Matheson, Victor A., 216. 


\section{Bibliography}

- Atkinson, R. (2003): "Introduction: Misunderstood Saviour or Vengeful Wrecker? The Many Meanings and Problems of Gentrification ",Urban Studies, Vol. 40. No.12, 2343-2350.

- Baade, Robert A., Matheson, Victor A. (2016): "Going for the Gold: The Economics of the Olympics", The Journal of Economic Perspectives, Volume 30, Number 2, April 2016, 201-218(18).

- Banks, J. A. (1998): “The Lives and Values of Researchers: Implications for Educating Citizens in a Multicultural Society“, Educational Researcher, 27(7), 4-17.

- Bartoluci Mato (2003): Ekonomika i menadžment sporta, Informator Zagreb i Kineziološki fakultet Sveučilišta u Zagrebu, Zagreb

- Bell, D., Jayne, M. (2003): 'Design-led' Urban Regeneration: a Critical Perspective", Local Economy, Vol. 18, No. 2, 121-134.

- Brown A., Massey J. (2001): Literature Review: The Impact of Major Sporting Events. The Sports Development Impact of the Manchester 2002 Commonwealth Games: Initial Baseline Research, Manchester Institute for Popular Culture, Manchester Metropolitan University.

- CFF - Croatian Football Federation Official Website http://www.hns-cff. $\mathrm{hr} /$ ?n=en (10. April 2012)

- Chanaron, J.J. (2014): “Technology and Economic Impacts of Mega-Sports Events: A Key Issue? Exploratory Insights from Literature“, Megatrend revija, Vol. 11, No. 4, 9-30.

- Chavez, C. (2008): "Conceptualizing from the inside: Advantages, complications, and demands on insider positionality", The Qualitative Report, 13(3), 474-494.

- 'Croatia and Hungary Bidding For UEFA EURO 2012' Official Websites http://euro2012.hns-cff.hr/?ln=hr (10. April 2012); http://www.eurofootball2012.hu/index_eng.php (10. April 2012)

- Europe's Football Website http://www.uefa.com (10. September 2012)

- Government of the Republic of Croatia (2006): Strategic Development Framework for 2006-2013, Central Office for Development Strategy and Coordination of European Union Funds, Zagreb, Croatia http://www.strategija.hr/datastore/filestore/16/Strateski_okvir_za_razvoj_2006_2013.pdf (10. September 2014)

- Gratton, C., Dobson, N., Shibli, S. (2000): “The economic importance of major sports events: a case study of six events", Managing Leisure, Vol. 5, 17-28.

- $\quad$ Gratton, C., Shibli, S., Coleman, R. (2005): "Sport and Economic Regeneration in Cities", Urban Studies, Vol. 42, No. 5/6, 985-999. 
- Gratton, C., Shibli, S., Coleman, R. (2006): “The economic impact of major sports events: a review of ten events in the UK", The Sociological Review, Vol. 54, No. 2, 41-58.

- Horne, J. (2007): “The Four 'Knowns' of Sports Mega-Events“, Leisure Studies, Vol. 26, No. 1, 81-96.

- Hrvatski rukometni savez (2006): Utjecaj ekonomike sporta na gospodarstvo i razvoj Hrvatske - Hrvatska domaćin Svjetskog prvenstva u rukometu za muške, Zagreb.

- Jutarnji list (2007a): "Hrvatskoj u mjesec dana Eura milijarda kuna samo od PDVa", 01. April 2007. http://www.jutarnji.hr/clanak/art-2007,4,1,,68703. jl (05. September 2015)

- Jutarnji list (2007b): “Euro 2012. stajat će nas 5,5 milijardi kuna”, 25. February 2007., http://www.jutarnji.hr/clanak/art-2007,2,25,markovic_hns,64104. jl, (12. September 2015)

- Jutarnji list (2010a): "Dobili smo još jednu maskotu koju ćemo vrlo brzo zaboraviti“, 23. August 2010. http://www.jutarnji.hr/dobili-smo-jos-jednumaskotu-koju-cemo-vrlo-brzo-zaboraviti/879987 (05. September 2015)

- Jutarnji list (2010b): "Financijskecrnerupe: SamoobavezniWC-iuMaksimirustoje 100.000 knpoutakmici!“, 05. September 2010.http://www.jutarnji. $\mathrm{hr} /$ samo-obavezni-kemijski-wc-i-u-maksimiru-stoje-100-000-kn-po-utakmici/883654 (05. September 2015)

- Matos, P. (2006): "Hosting mega sports events: A brief assessment of their multidimensional impacts", The Copenhagen Conference on the Economic and Social Impact of Hosting Mega Sports Events, Copenhagen.

- Monclus, F-J. (2003): "The Barcelona model: and an original formula? From 'reconstruction' to strategic urban projects (1979-2004)“, Planning Perspectives, Vol. 18, No. 4, 399-421.

- McCartney, GJ. (2005): "Hosting a recurring mega-event: Visitor raison d'etre", Journal of Sport and Tourism, Vol. 10, No. 2, 113-128.

- Mueller, M. (2014): “After Sochi 2014: costs and impacts of Russia’s Olympic Games", Eurasian Geography and Economics, Vol. 55, No. 6, 628-655.

- Nekić, M., Kulenović, A. (2008): "Upravljanje sportskim dvoranama”, 26. October 2008., http://www.liderpress.hr/Default.aspx?sid=57956 (15. July 2015)

- Ohmann, S., Jones, I., Wilkes, K. (2006): “The Perceived Social Impacts of the 2006 Football World Cup on Munich Residents", Journal of Sport and Tourism, Vol. 11, No. 2, 129-152.

- Paddison, R. (1993): "City Marketing, Image Reconstruction and Urban Regeneration", Urban Studies, Vol. 30, No. 2., 339-350.

- Raguž, K. (2009):"Zlatko Mateša: Još ne znamo kolika će biti konačna cijena održavanja Svjetskoga rukometnog prvenstva”, Intervju, 08. January 2009. http://www.liderpress.hr/Default.aspx?sid=64099 (15. July 2010.) 
- Rukometni savez Srbije (2012): Izveštaj sa Evropskog prvenstva Srbija 2012. http://rss.org.rs/files/Izvestaj_sa_Evropskog_prvenstva_Srbija_2012.pdf (22. December 2016)

- Sterken, E. (2006): "Growth Impact of Major Sporting Events“, European Sports Management Quarterly, Vol. 6, No. 4, 375-389.

- The Economist (2004): "A matter of priorities; those Olympic Games. Greece's costly Olympic Games", Sept. 4., v372. i8391,13US.

- Wilson, R. (2006): "The economic impact of local sport events: significant, limited or otherwise? A case study of four swimming events", Managing Leisure, Vol. 11, No. 1, 57-70.

- ZZabec, K: “Dvorane su gotove, tko će ih puniti”, 14. December 2008., http:// www.jutarnji.hr/nedjeljni_jutarnji/clanak/art-2008,12,14,,144937.jl, (20. december 2015)

- Zimbalist, A. (2015): “The Illusory Economic Gains from Hosting the Olympics \&World Cup“, World Economics, vol. 16, issue 1, 35-42. 
DR Ružica Šimić Banović, DOCENT

Pravni fakultet Sveučilišta u Zagrebu

Dr ANA Jurčić, DOCENT

Geoekonomski fakultet,

Univerzitet „Džon Nezbit”, Beograd

Dr Milan Petronijević, docent

Fakultet sporta i fizičkog vaspitanja, Univerzitet u Beogradu

\section{ORGANIZACIJA VELIKIH SPORTSKIH DOGAĐAJA U MALOJ ZEMLJI: (STVARNI) UTICAJ NA RAZVOJ - SLUČAJEVI HRVATSKE I SRBIJE}

Većina studija o uticaju sportskih zbivanja na razvoj zemlje nastaje pre održavanja istih $i$ kao takve uglavnom zagovaraju proces kandidature. Kada se te ex ante analize uporede s ex post nalazima, u većini slučajeva je jasno da su bile preoptimistične. Ovaj rad analizira ex ante dokumentaciju Hrvatske za kandidaturu za Evropsko prvenstvo u fudbalu 2012. Osim tih podataka, analiziraju se i ex ante studija pripremljena za Svetsko rukometno prvenstvo za muškarce koje je u Hrvatskoj održano 2009, te (deficitarni) podaci za rukometna prvenstva održana u Srbiji. Ovaj rad zato doprinosi, kako raspravi o realističnosti pristupa neuspeloj kandidaturi za EURO 2012, tako i o sledećim kandidaturama za druga sportska zbivanja.

Ključne reči: ekonomija sporta, menadžment i organizovanje, sportski događaji, prvenstva 
